OPEN ACCESS

Approved by:

Frontiers Editorial Office,

Frontiers Media SA, Switzerland

*Correspondence:

Frontiers Production Office production.office@frontiersin.org

Specialty section:

This article was submitted to Computational Genomics,

a section of the journal

Frontiers in Genetics

Received: 19 June 2020 Accepted: 22 June 2020

Published: 08 July 2020

Citation

Frontiers Production Office (2020)

Erratum: FluentDNA: Nucleotide Visualization of Whole Genomes, Annotations, and Alignments.

Front. Genet. 11:745

doi: 10.3389/fgene.2020.00745

\section{Erratum: FluentDNA: Nucleotide Visualization of Whole Genomes, Annotations, and Alignments}

\author{
Frontiers Production Office* \\ Frontiers Media SA, Lausanne, Switzerland
}

Keywords: data visualization, nucleotide visualization, genome assembly, genome browser, chromosome structural variants, genome alignment, comparative genomics, space filling curves

\section{An Erratum on}

FluentDNA: Nucleotide Visualization of Whole Genomes, Annotations, and Alignments by Seaman, J., and Buggs, R. J. A. (2020). Front. Genet. 11:292. doi: 10.3389/fgene.2020.00292

Due to a production error, there was an error in affiliation 1. Instead of "Richmond, VA, United Kingdom," it should be "Richmond, United Kingdom."

The publisher apologizes for this mistake. The original article has been updated.

Copyright $\odot 2020$ Frontiers Production Office. This is an open-access article distributed under the terms of the Creative Commons Attribution License (CC BY). The use, distribution or reproduction in other forums is permitted, provided the original author(s) and the copyright owner(s) are credited and that the original publication in this journal is cited, in accordance with accepted academic practice. No use, distribution or reproduction is permitted which does not comply with these terms. 